\title{
Strangers in Strange Worlds: Margaret Atwood's MaddAddam Trilogy
}

\section{Alan Northover}

To cite this article: Alan Northover (2017) Strangers in Strange Worlds: Margaret Atwood's MaddAddam Trilogy, Journal of Literary Studies, 33:1, 121-137

To link to this article: http://dx.doi.org/10.1080/02564718.2017.1290384

曲 Published online: 01 Mar 2017.

Submit your article to this journal ¿

Q View related articles $₫$

View Crossmark data \lceil 


\section{Strangers in Strange Worlds: Margaret Atwood's MaddAddam Trilogy}

\section{Alan Northover}

\section{Summary}

Strangeness, based on the ambivalence of the uncanny, characterises both the preand post-apocalyptic worlds of Margaret Atwood's MaddAddam trilogy. Whereas Spiegel (2010) makes a convincing case for the neomedievalism of the corporationdominated pre-apocalyptic world in Oryx and Crake, Atwood's post-apocalyptic world can perhaps more aptly be described as Palaeolithic or Neolithic in the special sense of a return to the Stone Age. However, both these worlds are fictional constructs, set in the near future, allowing Atwood to critique trends in the contemporary world. Both worlds make disturbing and alienating reading, despite - or pehaps because of - the dark sense of humour that Atwood exhibits and the strange familiarity of her imagined worlds. Besides the more general concepts of the sinister and the eerie, Russian Formalism's defamiliarisation and Freud's unheimlich (uncanny) are employed to understand different aspects the alienating effects that Atwood achieves. The animal gaze and the unmasking of the absent referent are also considered, particularly as experienced through Jimmy and Toby, Atwood's main narrative focalisers.

\section{Opsomming}

Beide die pre- en post-apokaliptiese wêreld van Margaret Atwood se MaddAddamtrilogie word gekenmerk deur vreemdheid wat berus op die teenstrydigheid van die bonatuurlike. Spiegel (2010) gee 'n oortuigende verklaring vir die neo-Middeleeuse gees van die pre-apokaliptiese wêreld in Oryx and Crake, waar korporasies die botoon voer. Daarteenoor sou dit waarskynlik meer gepas wees om Atwood se postapokaliptiese wêreld as palaeolities of neolities te beskryf, spesifiek in die sin van 'n terugkering na die Steentydperk. Albei hierdie wêrelde is egter fiktiewe konstrukte gesetel in die nabye toekoms, wat dit vir Atwood moontlik maak om 'n kritiese beskouing van tendense in die hedendaagse wêreld te gee. Beide wêrelde dra by tot ontstellende, vervremende leesstof, ten spyte van - en miskien weens - die donker humorsin wat Atwood openbaar. Defamiliarisasie, wat van die Russiese Formalisme afkomstig is, en Freud se unheimlich (geheimsinnig, buitengewoon) word benewens die algemene nosies van die boosaardige en onheilspellende ingespan om die vervremende effekte wat Atwood bewerkstellig, te verstaan. Die dier se starende blik en die ontmaskering van die afwesige referent word ook oorweeg, in die besonder soos ervaar deur Jimmy en Toby, Atwood se vernaamste vertellende fokaliseerders.

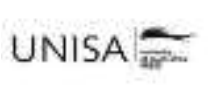




\section{Introduction}

Margaret Atwood famously rejected the term "science fiction" to describe those of her novels that some may be tempted to describe as such. Instead, she chose the term "speculative fiction," which concerns "things that really could happen but just hadn't completely happened when the authors wrote the books" (Atwood 2011: 6). This applies to her MaddAddam trilogy: Oryx and Crake (2003), The Year of the Flood (2010) and MaddAddam (2013). Everything that happens in the MaddAddam trilogy has clear precedents in contemporary society, and the effect is to create frighteningly alienating yet strangely familiar imaginative worlds. The trilogy describes a disturbing pre-apocalyptic world dominated by ruthless corporations, a global catastrophe called the Waterless Flood, and a post-apocalyptic world, an alien landscape with collapsing cities and populated by strange hybrid animals, unrestrained plant growth and very few humans. Yet nothing in her imaginative world can be called fantastic and everything is based on current social trends, such as technological developments and economic practices leading to environmental degradation. Indeed, their frightening effect derives largely from their very familiarity to the contemporary reader. Many of the details of her world can be described as bizarre or horrific, in the sense of gruesome, but the horror is largely offset by a pervasive dark and ironic humour. ${ }^{1}$ Huggan and Tiffin describe the "grotesque" effect of Oryx and Crake as "simultaneously ridiculous and terrifying" (2010: 209) and Bouson writes that "Atwood's MaddAddam trilogy is a dark satire, an Atwoodian 'joke-filled romp' through end times" (2016: 352) but discusses in detail Atwood's very serious underlying fears expressed in the endless horrors that she describes. Laughter is a mechanism readers use to cope with the horror. The combination of the frightening with the humorous may seem discordant, but Atwood blends these emotions masterfully in her novels. Nonetheless there is also another sub-class of the frightening operating in her novels, more subtle than gruesome, that can perhaps be identified as alienating. Mosca (2013: 40) mentions Freud's uncanny in relation to Atwood's trilogy - "We see that Margaret Atwood presents us once again with an uncanny product of speculative fiction" (2013: 45) - but focusses on the posthuman and transhuman. This article explores other aspects of strangeness, including the sinister and the uncanny, in Atwood's trilogy without resorting to the terms utopia or dystopia, terms which Atwood herself problematises (2006: 66-93).

1. I have explored the comical, polyphonic structure of the Trilogy in an article entitled "Ecological Apocalypse in Margaret Atwood's MaddAddam Trilogy", Studia Neophilologica, 2016, 88(1): 81-95. 


\section{Defamiliarisation, the Uncanny and the Eerie}

Complementing the more general concepts of the sinister and the eerie, Russian Formalism's ostranenie (defamiliarisation or making strange) and Freud's unheimlich (uncanny) are employed in this article to explain different alienation effects that Atwood creates in the trilogy. Although these concepts may seem slightly dated, they nonetheless help to illuminate different aspects of Atwood's trilogy. Victor Shklovsky emphasised the use of poetic devices to achieve estranging effects, the defamiliarisation of perception, the "habitual made strange" (Erlich 1981: 76). Defamiliarisation is expressed most clearly in the neologisms Atwood forms to describe the corporations, institutions, computer games, entertainment websites and hybrid, genetically modified animals that populate her fictional world: pigoons (a human-pig splice), wolvogs (a vicious wolf-dog splice), liobambs (a cross between sheep and lions), bobkittens (also very dangerous) and rakunks (a harmless rat-skunk splice). The corporate names include OrganInc, HelthWyzer, RejoovenEsense, CorpSeCorp and CryoJeenyus. However, her descriptions, using familiar words, of her vividly imagined pre- and post-apocalyptic worlds, which can be characterised as neomedieval and Neolithic, also have a deeply alienating effect, despite the darkly humorous tone that accompanies them. Atwood naturalises in her text scenes and scenarios what most contemporary readers will find outrageous or scandalous, for instance, the impunity with which the strong prey upon the weak in her imagined worlds.

The concepts of the absent referent and the animal gaze are also used to explore different aspects of the strangeness of Atwood's fictional worlds. Illustrating that defamiliarisation still has currency, Coetzee in Diary of a Bad Year (2007) discusses the importance of defamiliarisation in relation to meat: "It is important that not everyone should lose this way of seeing the kitchen - seeing it with what Viktor Shklovsky would call an estranged eye, as a place where, after the murders, the bodies of the dead are brought to be done up (disguised) before they are devoured" (2007: 63). A major thrust of this article is to show how Atwood unmasks the "absent referent," revealing how humans, particularly women and children, are treated as "meat" in both her fictional world and, by implication, contemporary society. Furthermore, in a central scene of the trilogy Atwood employs the animal gaze, arguably an extreme experience of defamiliarisation, since through it humans are decentred as subjects and become subject to the animal gaze, that is, experience themselves being viewed as objects by a nonhuman animal agent.

Freud's essay on the uncanny was a rare excursion of his into the field of aesthetics. Although Freud's uncanny primarily refers to a particular kind of psychological state experienced by actual patients, he argued that the "uncanny that we find in fiction - in creative writing, imaginative literature 
- actually deserves to be considered separately" (155) and that "fiction affords possibilities for the sense of the uncanny that would not be available in real life" (157). The uncanny in fiction also differs in kind from that in real life, "because the realm of the imagination depends for its validity on its contents being exempt from the reality test" (155). Freud identifies at least two sources of the uncanny, first, surmounted forms of thought (namely, superstition), and, second, repressed complexes, the uncanny consisting in the return of the repressed in both cases. He thus provides both an anthropological and a psychological basis for the uncanny. The former he links to primitive animism: "Let us take the uncanny effects associated with the omnipotence of thoughts, instantaneous wish-fulfilment, secret harmful forces and the return of the dead" (154). For Freud, these "primitive" or "superstitious" beliefs have been superseded, or "surmounted," by modern science. This article illuminates instances of both types of the uncanny in the MaddAddam trilogy in order to explain the particular alienating effect achieved in each case.

Atwood's MaddAddam trilogy is full of horrifying descriptions. However, eerie and the uncanny involve an ambivalent relationship between the familiar and the unfamiliar rather than the merely gory or gruesome. Atwood's speculative fiction provides a perfect platform for the uncanny, since her imagined, near-future worlds bear a disturbing similarity to our own. Her futuristic world unsettles her readers by spelling out the likely consequences in a world set in the near future of the frightening realities of current social trends that we prefer to forget or ignore. The corporatisation of society is one of them and the absent referent that conceals the truth about the treatment of animals on factory farms is another. Finally, Atwood also unsettles her readers in recreating a post-apocalyptic Stone Age, the imagined consequence of our current irresponsible behaviour.

This article explores both the uncanny worlds that Atwood creates in the trilogy as a whole and also analyses specific moments of the uncanny experienced by the narrative focalisers, Jimmy, Ren and Toby, showing them to be inhabitants of a strange land. Nonetheless, Atwood depicts even these characters, natives of the strange land, as experiencing uncanny or eerie moments, often involving pigoons, the most human-like of farmed animals. In the analysis that follows, Atwood's strange imaginative worlds are briefly commented on, after which the strange moments, whether uncanny or more generally alienating, experienced by Atwood's main narrative focalisers in all three novels are explored in more detail.

\section{Two Strange Worlds}

In a strangely familiar world that Spiegel has characterised as "neomedieval," national government has all but disappeared and the world is 
dominated by powerful corporations concerned solely with the pursuit of profit. A private security company, the CorpSeCorp (Corporation Security Corps) has taken over the policing of society. Spiegel (2010) borrows the term "neomedievalism" from the discipline of International Relations and persuasively applies it to the pre-apocalyptic world of Atwood's Oryx and Crake, where central governments and national states have lost their power and authority to corporations.

Spiegel invokes neomedievalism in order to counter critics who find Atwood's characterisation of Oryx and Crake to be "cardboardy". Crake is the nickname of Glenn, the young scientist who engineers the virus that kills off most of humanity and who designs the Crakers, eerily beautiful vegetarian hominids that have rabbit and cat features, to replace humans. Oryx is Crake's "exotic" girlfriend who helps him teach the Crakers survival skills. Spiegel argues that both Oryx and Crake survive by allowing themselves to be commodified physically and mentally, respectively, and thus have no subjectivity or affect, only multiple (schizophrenic) identities (Spiegel 2010: 128). They, therefore, exemplify the disintegration of the subject in "a late capitalist world trending towards the post-national" (2010: 133). Oryx and Crake can be considered eerie characters, since they resemble automata, like Olimpia, the life-sized automaton in Hoffmann's "The Sand-Man", the story analysed by Freud in his essay on the uncanny. The same applies to high ranking members of the corporations. Indeed, Ren (short for Brenda), the second narrative focaliser of The Year of the Flood, who works as a striptease artist, notes how unpleasant it is servicing the CorpSeCorp men, since "It was like they had machine parts in behind their eyes" (2010: 365).

Atwood's post-apocalyptic world is aptly characterised as Neolithic, where corporate power, indeed, civilization itself, has been destroyed and people have reverted to living in semi-nomadic bands, the relics of the previous civilization crumbling around them and kudzu vines overgrowing everything. In MaddAddam, Atwood has Toby reflect, much later in the narrative, after the Waterless Flood, that "Once we run out of optical products ... it really will be back to the Stone Age" (2013: 43).

Atwood's worlds are both familiar and strange to her readers in that they resemble both contemporary societies undergoing corporatisation and the return of earlier forms of society, palaeolithic and medieval. Animals are important in Atwood's imagined worlds. However, she describes very few animals familiar to contemporary readers; her fictional worlds appear to be populated largely by genetically modified hybrid animals, shaped purely for human - and corporate - interests. ${ }^{2}$ These eerily hybrid animals are the

2. Theissen (2013) and Narkunas (2015) explore the objectification and instrumentalisation of life forms for corporate profit in Atwood's novels. 
fictional embodiment of our current disrespect for nonhuman animals taken to logical extremes.

\section{$4 \quad$ Oryx and Crake}

In Oryx and Crake (2003), it is through the eyes of the narrative focaliser Jimmy that many of the uncanny aspects of the pre- and post-apocalyptic worlds are revealed, since he has a privileged insight into the products and workings of the corporations, which would prefer to have their secrets hidden. Through Jimmy's eyes and emotions, Atwood unmasks the absent referent. Critics have noted Atwood's depiction of women as "meat" in The Year of the Flood and have discussed the implicit cannibalism (Bouson 2011: 12-13; DiMarco 2011) and Wright (2015: 517) briefly mentions Carol Adams's concept of the absent referent to expose a hidden exploitation at work, the exploitation of animals. According to Adams, "the absent referent was what enabled the interweaving of the oppression of women and animals":

Once the existence of meat is disconnected from the existence of an animal who was killed to become that "meat", meat becomes unanchored by its original referent (the animal), becoming instead a free-floating image, used often to reflect women's status as well as animals'. Animals are the absent referent in the act of meat eating; they also become the absent referent in images of women butchered, fragmented, or consumable.

(Adams 2010: 13)

It is tempting to argue that Atwood's exposure of the absent referent represents a special form of Freud's return of the repressed, in that many readers repress their knowledge of what happens on factory farms only to have it exposed in Atwood's fiction. However, this may be stretching the point. The exposure of the absent referent is evident early in Oryx and Crake (2003), the first novel in the MaddAddam trilogy, where the narrative focaliser, the young child Jimmy, experiences as highly alienating the way the pigoons (a human-pig genetic splice) are treated by the scientists at OrganInc. Through him Atwood exposes the absent referent as the scientists eat the bodies of the pigoons that they have developed for the purpose of xenotransplantation despite the suggestion of cannibalism: "Jimmy didn't want to eat a pigoon, because he thought of the pigoons as creatures much like himself" (2003: 24). The name OrganInc is eerie in that it resembles "organic" but, since it involves genetic engineering, is the frightening opposite of that.

Even earlier, "Jimmy's earliest complete memory was of a huge bonfire" (2003: 16), and the "bonfire was an enormous pile of cows and sheep and pigs" (2003: 16). Holding an infantile belief (one of the sources of the 
uncanny), Jimmy does not want to walk through the pan of disinfectant, because he wants to avoid it getting into the eyes of the smiling duck's faces on the end of his plastic boots. It is significant that these scenes are experienced through the eyes of a child. Shklovsky contended that poetry "restores to us the fresh child-like vision of the world" (1981: 76). As he grows into adulthood, however, Jimmy's responses to animal suffering become desensitised and automatised. He eventually overcomes his disgust and eats ChickieNobs or Nubbins: wart-like growths of a brainless, regenerating genetic monster that are passed off as chicken (2003: 202-203, 315).

Nonetheless, in a metaphorical return of the repressed, Jimmy's frightening childhood experiences with pigoons recur in his adulthood, towards the end of Oryx and Crake, when, as supposedly the last human alive in the post-apocalyptic world, he is hunted by the pigoons. Jimmy experiences an eerie sensation when he notices how intelligently the pigoons appear to be hunting him and he experiences a disturbing shift of perception when he imagines how the pigoons must see him: "What they see is his head, attached to what they know is a delicious meat pie just waiting to be opened up" (2003: 268). The pigoons, superficially resembling pigs, exhibit disturbingly human-like behaviour. Readers may also experience as alienating the way pigoons turn the tables on humans, the exploiter becoming the hunted. Atwood perturbs her readers by ousting humanity from a position of power that most people take for granted today, where animals are reduced to mere tools for human use and are processed out of sight of the general public on animal farms, in slaughter houses and in laboratories.

\section{The Year of the Flood}

The unmasking of the absent referent contributes to the sense of strangeness that pervades The Year of the Flood (2010), the second instalment of the MaddAddam trilogy, as experienced by the two narrative focalisers, Ren and Toby. Toby represents a figure of good, practical sense, without illusions and without a belief in a supernatural order. She nonetheless experiences uncanny moments, particularly in relation to her friend and mentor, Pilar. These uncanny moments relate to Freud's idea of the return of surmounted thoughts. In these moments, Toby's rationalism is challenged by experiences that cause her to consider the possibility of a spirit world. Unlike the central characters of Oryx and Crake, Glenn and Jimmy, who are males from privileged backgrounds, brought up in elite compounds, Toby, the primary narrator of The Year of the Flood and MaddAddam, is born and raised in the pleeblands, crime- and disease-ridden areas where most people live, often in poverty, insecurity and danger. Toby's mother dies after being 
the unwitting subject and victim of drug tests by the company that employs her, and Toby's father, unable to cope financially and emotionally, commits suicide, leaving Toby to cope on her own. She is forced to drop out of the second rate Martha Graham Academy for which she had received a meagre scholarship and to seek a living. She tries several low-paying jobs and sells her hair. She earns large payments on two occasions when selling her ovaries, but an infection incurred during the second donation renders her sterile. Toby's having to sell her hair and ovaries is part of Atwood's critique of the commodification of the female body, implicit in the absent referent. Finally, she finds work as a barista at a SecretBurgers franchise secret because "no one knew what sort of animal protein was actually in them" (2010: 40) - managed by the psychopath Blanco. He treats his female employees as "meat," using them in succession as sex slaves until they are worn out and then disposing of them - sometimes even using their bodies in burger patties.

Ren, the second narrator in The Year of the Flood, is not intelligent enough to go to one of the better science academies and ends up going, like Jimmy and Toby (for a while), to the Martha Graham Academy. She graduates with a useless degree and ends up working as a striptease artist in Scales and Tails, deep in the pleeblands. The concept of the absent referent clearly applies to this high-end sex club, since the girls dress up in bird or reptile outfits in order to excite their customers, many of whom are senior executives from the corporations, the same class of people that consumes the bodies of exotic and endangered animals at illegal restaurants such as the one called Rarity (2010: 453). Thus the exploitation of exotic dancers dressed in animal outfits reveals another form of exploitation and the consumption of exotic animals reiterates the exploitation of women. This is summed up in the word "Tails", which refers both to animals and, in vulgar slang, to women as sexual objects. Atwood's unmasking of the absent referent in the case of Ren can be seen both as darkly humorous and deeply disturbing.

Ren was also a child Gardener for a while after her mother escaped an elite compound temporarily to join the God's Gardeners. Ren escapes the Flood because she is confined in the recovery unit of Scales and Tails, since she may have been infected by a customer (not by the super-virus though). She is locked in with diminishing food supplies until her childhood friend Amanda rescues her. Later three other former Gardeners - who go on to become MaddAddam eco-activists - and childhood acquaintances, Shackie, Crozier and Oates find them there. They are soon forced to leave the club, since three dangerous criminals (including Blanco, Toby's oppressor) are pursuing them. Ren remains a fragile and vulnerable character, requiring protection from stronger characters to avoid falling prey to the predatory males of Atwood's futuristic worlds. Vegetarian herself, she remains potential "meat" to men. However, her rejection of meat can be seen as a 
form of subliminal resistance to her being treated as "meat". Her job as an exotic dancer in animal costume signifies a deeper exploitation at work, the oppression of animals, which has been erased under the absent referent. By drawing attention to Atwood's uncanny unmasking of the absent referent, revealing that which should be hidden, this article reveals her critique of animal exploitation, closely related to the exploitation of women.

The absent referent also applies to Toby's case, but with a different emphasis. Starting from a position of victimhood, Toby gradually transforms into a somewhat reluctant leader figure in the apocalyptic and post-apocalyptic "Neolithic" period and, unlike Ren, shows impressive independence and survival skills. Her eventual rejection of meat arguably shows her liberation from the dominant patriarchal "text of meat" that objectifies women and animals, thereby justifying their exploitation. Having been treated as "meat" by her psychopathic boss Blanco, owner of a SecretBurgers franchise, and having been saved from being murdered by him by the God's Gardeners (2010: 47-51), an eco-religious vegetarian cult, Toby develops a highly ambivalent attitude towards meat. At the same time, she is critical of the "theology" - the myths and rituals - of the God's Gardeners, finding it "scrambled" (2010: 56). Nonetheless, Toby feels grateful to Adam One for saving her from Blanco, and she submits to the Gardeners' disciplined existence in the Edencliff Garden atop a high rise building in the heart of the pleeblands.

When Burt, one of the Adams, is arrested by the CorpSeCorp for running a marijuana racket, Adam One asks Toby to do an overnight Vigil. He wants her to take a concoction that includes of quantity of a hallucinogenic mushroom (Amanita Muscaria) in order to achieve a spiritual experience to see if she can find it in herself to take over Burt's botanical classes. She reluctantly agrees but keeps her skeptical thoughts to herself. She responds to her vision with the words "You are the effect of a carefully calibrated blend of plant toxins" (2010: 204). This echoes Atwood's own skeptical words, "to seek God in altered brain chemistry", in her collection of critical essays, In Other Worlds (2011: 192). However, despite her skepticism, it remains an otherworldly experience. Toby sees a vision of a strange animal golden in colour, "with gentle green eyes and canine teeth, and curly wool instead of fur. It opened its mouth, but it did not speak. Instead, it yawned" (2010: 204). The creature she sees is a liobamb, a genetically engineered lion-sheep splice, one of the eerie creatures that populate the imaginative world created by Atwood.

Toby is also apprenticed to Pilar, one of the Eves, who teaches her mushroom and bee-keeping lore, and who, on her death bed, wills her possessions and position as Eve Six to Toby, including her bee hives (2010: 214-215). Pilar is dying of cancer and, with the cancer at an advanced and irreversible stage, instructs Toby to administer (unwittingly) a fatal dose of the Amanita (Death's Angel) mushroom to her. Despite being a scientist, 
Pilar appears to believe in the existence of a spirit world, the type of belief that Freud identifies as one of the sources of the uncanny, that is, surmounted beliefs. Toby, however, has her private doubts about the existence of a spirit world, even though it is central to the God's Gardeners' belief system. When Pilar dies, Toby nonetheless experiences an uncanny moment:

Was it her imagination or had the candle flared up at the moment of Pilar's death as if a little surge of air had passed it? Spirit, Adam One would say. An energy that cannot be grasped or measured. Pilar's immeasurable Spirit. Gone.

But if Spirit wasn't material in any way, it couldn't influence a candle flame. Could it?

(2010: 215)

Honouring her promise to Pilar despite her doubts, Toby goes to tell the bees about Pilar's death even though she feels foolish doing so: "Bees were the messengers between this world and the other worlds, Pilar had said. Between the living and the dead" (2010: 215). After Pilar dies, her body is secretly buried in a public park and an elderberry shrub, a bush that attracts bees, is planted above her body (2010: 222). An adolescent observes the funeral at a distance. Unknown to Toby, he is the young scientist Crake (Glenn).

Blanco tries to exact revenge on Toby for escaping him and humiliating him publicly. After a botched raid on the Edencliff Garden by Blanco and his two henchmen (both of whom die in the raid), where Toby sets three hives of bees onto them (2010: 303), Adam One relocates Toby in secret to the AnooYoo Spa, which also conceals a Truffle (underground resistance) cell. He does so both for her protection and for that of the Edencliff community, since the CorpSeCorp is beginning to tighten the screws on the God's Gardeners. Toby adopts a new identity at the AnooYoo Spa - her new name "Tobiatha"- and is installed as its manager. She secretly turns it into an Ararat, as God's Gardeners have done in several other places, storing useful items and dried vegetarian food, despite her doubts about the eventuality of the Waterless Flood (2010: 316). This catastrophic event does occur a few years later in the form of a global pandemic, engineered by the scientist Crake, during which almost all humans die.

Isolated in the AnooYoo Spa, Toby survives the Flood, but only thanks to both the skills and the theology she has acquired as a God's Gardener. Hoogheem (2012: 64) has noted that it is as much the rituals and myths of the cult as the skills they teach, that enable the Gardeners to survive the Flood and its aftermath. The theology and rituals help her to retain her sanity during her extended period of isolation. She also makes, in the early phases of the Waterless Flood, a covert visit to her parents' house to retrieve the rifle that her father taught her to use and which he used to commit suicide. 
She waits out the Flood, her food supplies growing lower and tries to grow a vegetable garden to supplement them. However, pigoons discover her garden and raid it. She considers abandoning her vegetarianism and becoming completely carnivorous (2010: 434), since the pigoons have destroyed her garden and she is slowly starving. Nonetheless, when she does shoot a boar dead, she decides to leave his body where it falls and not to take it for meat (2010: 22-23). She does, however, visit it later to harvest the maggots and finds it to be covered with fronds as though it has been buried symbolically (2010: 390-394). This eerie moment shakes her. Toby continues to have reservations (throughout MaddAddam, too) about eating meat even once she has joined the surviving God's Gardeners and MaddAddams, who have reverted to hunter-gathering, pastoralism and limited cultivation - they are growing a vegetable garden (2010: 468).

Blanco and two fellow painballers, repeat criminal offenders (murderers), also survive the Flood since, at the time of its onset, they are isolated in a penal facility where, before the Flood, criminals are divided into teams to kill each other off in televised shows, the survivors being set free and becoming celebrities. They often end up murdering again, like Blanco, and so end up repeatedly in the Painball Arena. The painballers represent an unmasking of the absent referent, since they often "butcher" their victims and eat their kidneys in order to intimidate the opposing team (2010: 118). They are described as no longer being human - "Nothing much human left inside that scar tissue of theirs" (2010: 155) - as a result of their brutalisation. When they escape the facility after the Flood, Blanco and his partners capture Ren (dressed in a Scales and Tails bird outfit) and Amanda, and take them as sex slaves. They also "butcher" Oates, the brother of Crozier and Shackleton (2010: 450), another unmasking of the absent referent, although horrifying than uncanny. Ren manages to escape to the AnooYoo Spa. Toby shoots Blanco with her rifle (wounding him), rescues Ren and restores her to health. They then set out to find the surviving Gardeners and MaddAddams. On the way, they find a dying Blanco, whom Toby tricks into taking a fatal dose of poison. She decides to leave his excellent knife behind, "Good tool, but bad karma" (2010: 462), thereby displaying a regression to surmounted forms of thought. They discover and join a small encampment of Gardeners and MaddAddams. Some days later, Toby and Ren set out to try to save Amanda from the painballers. They find the painballers' camp and wait in ambush, Toby poised to shoot with her rifle. Before she can act, Jimmy approaches the painballers (picking up the action on which Oryx and Crake ended), armed with a spraygun but barely able to aim it. Toby and Jimmy manage to disarm and tie up the painballers. However, the criminals manage to escape during the chaos that ensues after a party of Crakers appears on the scene and free them. The savage actions of the painballers and the name itself - a reference to "paintball" - are 
disturbing references to current social practices and serve to unmask the absent referent in "meat".

\section{MaddAddam}

MaddAddam (2013), the final novel of the trilogy, opens with Toby waiting in ambush armed with her rifle, viewing the painballers' campsite where Amanda is tied to a tree. Toby reflects:

Anyone who'd survived Painball more than once had been reduced to the reptilian brain. Sex [with their female victims] until you were worn to a fingernail was their mode; after that, you were dinner. They liked the kidneys.

(2013:9)

DiMarco (2011: 134-135) discusses, in relation to Atwood's work, cannibalism in the form of the Wendigo, a Native American mythical being that represents extreme selfishness. DiMarco argues, however, that this figure also represents, in Atwood's fiction, the destructive greed of global capitalism, and Bouson writes of "corporate cannibalism" (2011: 12). What DiMarco and Bouson appear to miss is the absent referent operating within the idea of cannibalism, namely, that the animal erased under the absent referent. The consumption of human flesh by humans is considered reprehensible, whereas eating the flesh of other animals is considered uncontroversial.

The animal gaze has become a key aspect of animal studies, including the topic of an entire book by Wendy Woodward (2008). Two key essays in the concept of the animal gaze are John Berger's "Why Look at Animals?" (1980) and Jacques Derrida's "The Animal that Therefore I Am (More to Follow)" (2002). While both Berger and Derrida emphasise the alterity of animals, on account of their lack of language, both also point out how, like humans, "Animals are born, are sentient and are mortal" (1980: 2). Berger argues that human identity is inextricably related to the independent existence of animals - "Man becomes aware of himself returning the look [that is, the animal gaze]" (1980: 3). Yet, Berger points out that the "19th century, in western Europe and North America, saw the beginning of a process, today being completed by corporate capitalism, by which every tradition which has previously mediated between man and nature was broken" (1980: 1). Derrida's famous essay "The Animal That Therefore I Am" (2002) originated as a result of the philosopher experiencing shame while being subjected, while naked, to the gaze of his small cat. Derrida rejects approaches that promote sympathy for animals on the basis of some positive similarity and argues, instead, that what is of significance is a profound lack that we share with animals: our suffering, vulnerability and 
mortality (2002: 396). Woodward (2008) develops the idea of the animal gaze in terms of animal subjectivity and agency.

This article contrasts the animal gaze - whereby animals assert their subjectivity and agency - to the absent referent - where animals are reduced to mere objects. In MaddAddam (2013), Toby's excursion to Pilar's burial place is necessitated by the fact that three of the female God's Gardeners and MaddAddams fall pregnant. The male Crakers, genetically engineered, peaceful vegetarian hominids, are the most likely fathers. The possible exception is Amanda, since she may have been impregnated by one of the painballers and, as a result, is emotionally devastated. If the father is, indeed, one of the painballers, she would prefer an abortion, although the community lacks the facilities to conduct safe abortions (2013: 215).

Furthermore, since the Crakers grow so much more quickly than humans, the community is concerned about what could happen to the women should the pregnancies come to term. In another apparent regression to surmounted forms of thought, Toby decides that they should consult with the spirit of Pilar, whose body is buried beneath an elderberry bush. In the postapocalyptic period, a visit to the Heritage Park is not safe - for not only are the painballers still at large, but there are packs of wolvogs, pairs of liobambs and herds of pigoons around - and so Toby is escorted there by Zeb and two other MaddAddams, with Blackbeard, the Craker boy, insisting that he accompany them. Circumstances dictate that Toby be accompanied by friends, especially as she is in a vulnerable, mushroom-induced altered state of consciousness in preparation for her communication with Pilar's spirit. As she puts it "I'll be accessing my inner Pilar" (2013: 219). After the event, she reappears to reassess her earlier dismissal of visions as mere neurological manipulation: "I was communicating with my inner Pilar ... And just because a sensory impression may be said to be 'caused' by an ingested mix of psychoactive substances does not mean it is an illusion" (2013: 227).

One's perceptions are defamiliarised and the world takes on an otherworldly aspect when one is in a state of altered consciousness, which involves all senses, including synaesthesia. In Toby's case it involves heightened visual, somatic and auditory experiences (2013: 221-223). Toby experiences "Shackleton's voice coming to her along a dark tunnel" (2013: 221), objects around her seem to be emitting light (2013: 222) and "All around there are sounds, noises, almost-voices: hums and clicks, tappings, whispered syllables" (2013: 222). It is in such a state that Toby experiences the gaze of the sow whose mate she has killed. When, standing at Pilar's elderberry bush, Toby asks Pilar questions but receives no answers, she turns her head and sees a huge pigoon sow with five farrow. Zeb is ready to shoot the sow but Toby asks him not to:

The sow stops, turns sideways: a perfect target. She looks at Toby out of her eye. The five little ones gather in her shadow, under the nipples, which are 
all in a row too, like vest buttons. Her mouth upturns in a smile, but that's only the way it's made. Glint of light on a tooth.

$\ldots$

The sow does not move. Her head remains up, her ears pricked forward. Huge ears, calla lilies. She gives no sign of charging. The piglets freeze in place, their eyes red-purple berries. Elderberry eyes.

The next moment, the sow and her young have vanished. Blackbeard turns to smile at Toby. "She was here," he says. What does he mean?

"Crap," says Shackleton. "There go the spare ribs."

So, thinks Toby. Go home, take a shower, sober up. You've had your vision."

(2013: 223)

Shackleton's superficial quip unmasks the absent referent in contrast with Toby's deeper encounter with the sow's gaze. The fact that the pigoon is female with farrow makes the connection between females and animals in the dominant text of meat clearer. The sow's fecundity also reassures Toby that the pregnant humans - especially Amanda - need not fear bringing their pregnancies to term. Pilar, to whom Blackbeard apparently refers, has answered Toby's questions not in words but in the form of a vision. The reference to "Elderberry eyes" decisively connects the sow to Pilar. Toby has been subjected to the destabilising experience of the gaze of an individual animal and is no longer able to eat the flesh of a pigoon. Indeed, she goes on, as mediator, with the help of Blackbeard, who can communicate with the pigoons, to negotiate a treaty between the surviving humans and the pigoons, although it is the pigoons who initiate this pact, thus demonstrating animal agency (2013: 270). The terms of the treaty are that the pigoons refrain from eating humans and raiding the humans' vegetable garden and bee hives on condition that the humans do not kill the pigoons for meat (2013: 270, 370, 378). They also agree to join together to fight the remaining painballers and an unknown third man.

Later, Toby recounts her experience with the sow at Pilar's grave to Rebecca, whose flippant remarks about the animals as meat fit uncomfortably with her former life as vegetarian cook of the God's Gardeners:

"I saw a giant pig yesterday," says Toby. "A sow, with piglets."

"The more the merrier," says Rebecca. "So long as we've got sprayguns. I'm running out of bacon."

"No, wait," says Toby. "It - she gave me a very strange look. I got the feeling that she knew I'd shot her husband. Back at the AnooYoo Spa."

"Wow, you really went to town on the mushrooms," Rebecca says .... So, was she mad about the .... I'm sorry, I just can't call it a husband! It was a pig, for chrissakes!"

"She wasn't pleased," says Toby. "But more sad than mad, I'd say."

(2013: 262-263) 
After her self-induced hallucinogenic, destabilising experience, Toby experiences a deep change, a shift in her attitude towards animals, or at least towards pigoons. The morning after her experience with the sow and after a night of vivid dreams, Toby "can't manage the ham, not after a night of waltzing piglets. And not after yesterday: what the sow communicated to her is still with her, though she couldn't put it into words" (2013: 261). She realizes that the sow is not only a mother, but an individual, whose mate Toby has shot and killed. Whereas Rebecca calls the sow an "it", Toby insists on calling the sow "she". At the same time, Toby's perturbing vision is correct, since all the women eventually safely give birth to human-Craker hybrids (2013: 377, 379).

\section{Conclusion}

Through the focalisation of Jimmy, Ren and Toby's experiences within their fictionalised worlds, Atwood defamiliarises aspects of contemporary society by projecting them into the near future, revealing "that which should remain hidden" and forcing readers to confront things that they would rather forget and ignore. Foremost among these are the corporatisation of society and our current mistreatment of animals. The disturbing effects of the strange familiarity are evoked both in the two strange worlds created by Atwood and in uncanny and eerie moments that she has her narrators experience. Animals are central to this, particularly the strangely familiar yet unfamiliar pigoon, which is not only the most human-like of farmed animals but, in Atwood's world, contains human genetic material. A sense of estrangement is not simply represented in how the narrators view the pigoons, but, more eerily, how they are subject to a disturbing and destabilising animal gaze. Some of the strangeness of Atwood's MaddAddam trilogy is a result of her activation of the uncanny and her defamiliarisation of the readers' perceptions, through both humour and horror, in the strange familiarity of her imagined worlds. She both engages and unsettles her readers by showing the likely consequences in the near future of the current treatment of women, animals and the environment.

\section{References}

Adams, C.

2010 The Sexual Politics of Meat: A Feminist-Vegetarian Critical Theory. Twentieth Anniversary Edition. London: The Continuum International Publishing Company Ltd.

Atwood, M.

2003 Oryx and Crake. London: Bloomsbury.

2010 The Year of the Flood. London: Virago. 
2011 In Other Worlds: SF and the Human Imagination. New York: Double Day.

2013 MaddAddam. London: Bloomsbury.

Berger, J.

1980 About Looking. London: Writers and Readers Publishing Cooperative Ltd.

Bouson, J.B.

2011

2016 A "Joke-filled Romp" Through End Times: Radical Environmentalism, Deep Ecology, and Human Extinction in Margaret Atwood's Eco-Apocalyptic MaddAddam Trilogy. The Journal of Commonwealth Literature 51(3): 341-357.

Coetzee, J.M.

2007 Diary of A Bad Year. London: Harvill Secker.

Derrida, J.

2002 The Animal That Therefore I Am (More to Follow). Critical Inquiry 28(2): 369-418.

DiMarco, D.

2011 Going Wendigo: The Emergence of the Iconic Monster in Margaret Atwood's Oryx and Crake and Antonia Bird's Ravenous. College Literature 38(4): 134-155.

Erlich, V.

1981 Russian Formalism: History - Doctrine. 3rd Edition. New Haven \& London: Yale University Press.

Freud, S.

2003 The Uncanny. Trans. David McLintock. London: Penguin Books. Hoogheem, A.

2012 Secular Apocalypses: Darwinian Criticism and Atwoodian Floods. Mosaic 45(2): 55-71.

Huggan, G. \& Tiffin, H.

2010 Postcolonial Ecocriticism: Literature, Animals, Environment. London and New York: Routledge.

Mosca, V.

2013 Crossing Human Boundaries: Apocalypse and Posthumanism in Margaret Atwood's Oryx and Crake and The Year of the Flood. Other Modernities 9: 38-52.

Narkunas, J.P.

2015 Between Words, Numbers and Things: Transgenics and Other Objects of Life in Margaret Atwood's MaddAddams. Critique 56: 125.

Spiegel, M.

2010 Character in a Post-national World: Neomedievalism in Atwood's Oryx and Crake. Mosaic 43(3): 119-134.

Theissen, A.

2013 The Management of Life in Atwood's Dystopian Fiction. Margaret Atwood Studies 7: 24-33. 
Woodward, W.

2008

The Animal Gaze: Animal Subjectivities in Southern African Narratives. Johannesburg: Wits University Press.

Wright, L.

2015 Vegans, Zombies, and Eco-Apocalypse: McCarthy's The Road and Atwood's Year of the Flood. Interdisciplinary Studies in Literature and Environment 22(3): 507-524.

\author{
Alan Northover \\ University of South Africa \\ northra@unisa.ac.za
}

